\title{
THE PARODY OF MUSICAL INSTRUMENTS IN MEDIEVAL ICONOGRAPHY*
}

\author{
Sandra PIETrini \\ Università degli Studi di Trento (Italia) \\ sandra.pietrini@unitn.it
}

During the late $13^{\text {th }}$ century, a very particular practice stands out in Franco-Flemish iconography: the parody of musical instruments. This subject has a particular persistence in the illuminated manuscripts of the Franco-Flemish area and reaches its climax during the $14^{\text {th }}$ century. The artists depart from the idea of an absurd employment of common, everyday objects, used as improper musical instruments, such as a man playing a vielle with a rake, accompanied by a woman dancing (Fig. 1), a woman playing tongs with a spoon $^{1}$, or a hybrid playing a wheat sheaf with a rake (Fig. 2). The monstrosity of these players is sometimes emphasised by resorting to a demoniac or ferine involution of their appearance, such as a hybrid man playing bellows with tongs ${ }^{2}$, or more rarely recurring to disguisement, such as in a miniature showing a man with a pot on his head playing a grill with tongs ${ }^{3}$.

\footnotetext{
${ }^{*}$ Este estudio se ha desarrollado en el marco del proyecto de investigación «Traza y figura de la danza en la larga Edad Media. Corpus iconográfico, textual y etnográfico en la Peninsula Ibérica y su proyección latinoamericana» (MINECO, FFI2013-42939-P).

${ }^{1}$ Cambridge, Trinity College Library, ms. B.11.22, f. 191v.

${ }^{2}$ Arras, Bibliothèque Municipale, ms. 229, f. $187 \mathrm{v}$.

${ }^{3}$ Oxford, Bodleian Library, ms. Douce 5, f. 164v.
} 

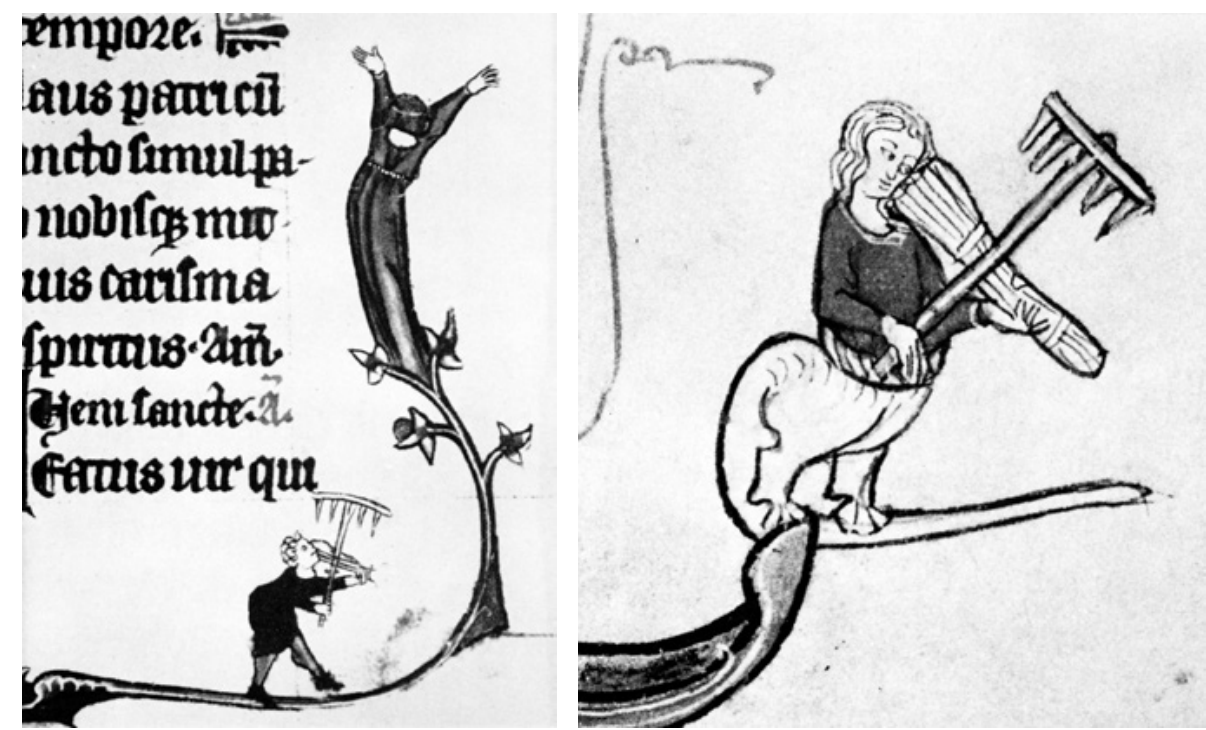

Fig. 1 (Left). Chantilly, Bibliothèque et Archives du Château de Chantilly, ms. 62, f. 117. Fig. 2 (Right). Bruxelles, Bibliothèque Royale, ms. 9391, f. 113v.

If we examine these bizarre objects used as musical instruments we soon discover that they come from two different contexts: the worlds of agricultural and culinary activities. What is the aim of this choice? The idea of music as a maddening noise can be found in a precise folkloric context, the charivari, a burlesque procession organized by the members of a community to stigmatize some socially blameworthy and censurable behaviour - such as the second wedding of a widow or the marriage of a woman with a man much younger than herself $f^{4}$. Through a ritual staging of disorder and an inversion of hierarchy, the charivari is motivated by an anthropological need for social control and its persistence is confirmed by numerous interdictions on the part of civil and religious authorities, repeated over and over even after the late Middle Ages ${ }^{5}$. Besides assuming a licentious character, the charivari employed disguising with masks of animals or sexual inversions, unseemly dancing and making music on improper instruments such as pots and pans, apt to produce cacophonic sounds instead of a pleasant melody. The noise

\footnotetext{
${ }^{4}$ On the charivari and its symbolic implications see Martine Grinberg, «Charivaris au Moyen Âge et à la Renaissance. Condamnation des remariages ou rites d'inversion du temps?», in Le Charivari, ed. by J. Le Goff and J.-C. Schmitt, (Actes de la table ronde organisée à Paris, 25-27 avril 1977 par l'École des Hautes Études en Sciences Sociales et le Centre National de la Recherche Scientifique), Paris-La HayeNew York, Mouton, École des Hautes Études en Sciences Sociales, 1981, pp. 141-147.

${ }^{5}$ François Lebrun, «Le charivari à travers les condamnations des autorités ecclésiastiques en France du XVI $I^{\mathrm{e}}$ au XVIII ${ }^{\mathrm{e}}$ siècle», in Le Charivari, op. cit., pp. 221-228.
} 
caused by the employment of common objects like pots and cowbells had also the purpose of attracting the attention of the inhabitants of the village where the comical procession took place.

The analogy between these absurd musical instruments and the parody depicted in the miniatures is rather evident. We can see an example of charivari in two well-known illustrations from a $14^{\text {th }}$ century manuscript of the Roman de Fauvel, a satiric poem by Gervais du Bus and Raoul Chaillou describing the adventures of the ass of the title, representing the worst human vices ${ }^{6}$. Here a burlesque procession organized as a mockery of Fauvel's marriage with Madame Fortune is depicted. The idea of music as noise recurs in these forms of musical parody, but while in the Roman de Fauvel it is part of the narrative, and related to a specific episode, in the margins of Gothic manuscripts the topic seems to be repurposed as a humorous theme, not necessarily linked to a specific performance of the folklore.

\section{The conception of Music between high and low}

Parody of musical instruments has a satirical purpose which could be linked to the attitudes toward players during the Middle Ages. As is known, music was part of the quadrivium, and had a high reputation among the arts, but attitudes toward various musicians depended upon the place they occupied on an ideal hierarchical scale. Medieval classifications of instruments were mostly founded on the difference between high and low, key and nonkey instruments. Percussion instruments were placed, for instance, on the lower level of this hierarchy, since they do not require knowledge of music, while the harp and all other string instruments were placed at the top. As Reinhold Hammerstein has pointed out, an essential difference occurs between measurable music, founded on mathematical proportions reflecting the cosmic order, and music which doesn't require learning its principles: this is in fact a distinction between ars and usus, the systematic order of theory and the empiric disorder of praxis 7 . This distinction dates back at least to the $6^{\text {th }}$ century, to Boethius' De institutione musica, where the learned musician who knows the ratio, the theory, occupies a higher level while the simple executioner, named after the instrument he plays, occupies the lowest one ${ }^{8}$. An illustration from a $14^{\text {th }}$ century Italian manuscript of Boethius' treatise

\footnotetext{
${ }^{6}$ Roman de Fauvel, Paris, Bibliothèque Nationale, ms. fr. 146, ff. 36v, 34r.

${ }^{7}$ On this dichotomy are based most of the observations made by Reinhold Hammerstein, Diabolus in Musica. Studien zur Ikonographie der Musik im Mittelalter, Bern-München, Francke, 1974.

${ }^{8}$ Boethius, De institutione musica, $\mathrm{X}$.
} 
depicts an allegory of Music (Fig. 3), represented as a gentlewoman sitting on a throne in the middle and playing a portative, while David with his harp appears in a medallion at the top. As we can see, the other players, inspired by contemporary court musicians, are disposed in a hierarchical order, with stringed instruments above and percussive ones below.

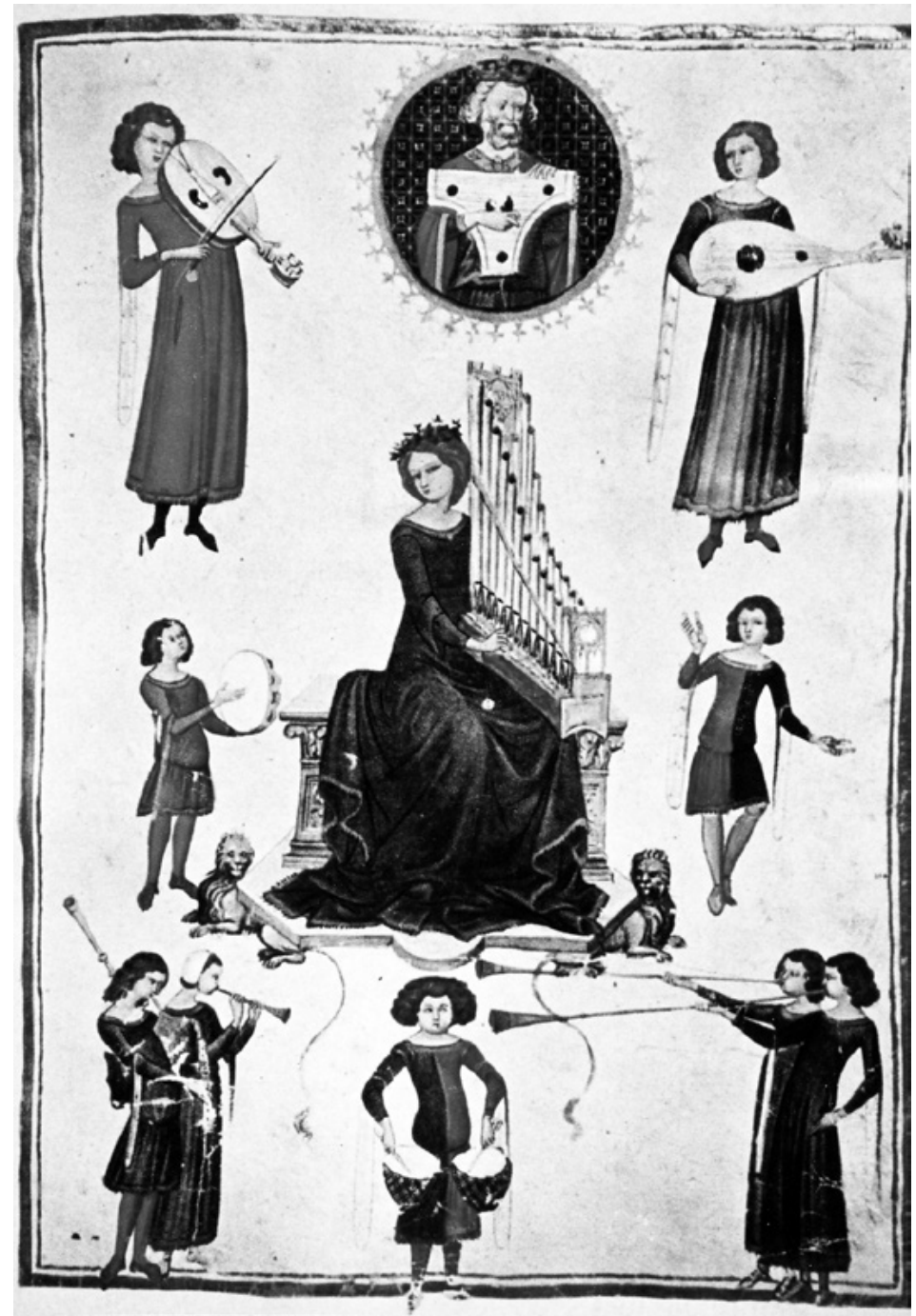

Fig. 3. De Musica, Napoli, Biblioteca Nazionale, ms. V.A.14.

With the kind permission of the «Ministero per i Beni e le Attività Culturali».

In spite of this clear opposition, we can find in medieval iconography a large number of ambiguous and puzzling examples. Monsters, hybrids and 
infernal creatures usually play wind and percussion instruments, sometimes with attitudes typical of contemporary entertainers ${ }^{9}$ (Fig. 4), but it is not so infrequent to stumble on negative figures playing prestigious instruments, such as a harping devil plucking the tongue of a sinner in the tympanum of the western portal of Sainte-Foy abbey church at Conques (Aveyron), dating about 1130 (Fig. 5). Such evident superposition of elements (a noble instrument played by a devilish creature) is possibly aimed at having a sort of shock effect on the viewer. In fact, because of the composite character of medieval imagery, all musical instruments can assume different connotations and meanings according to the context ${ }^{10}$.

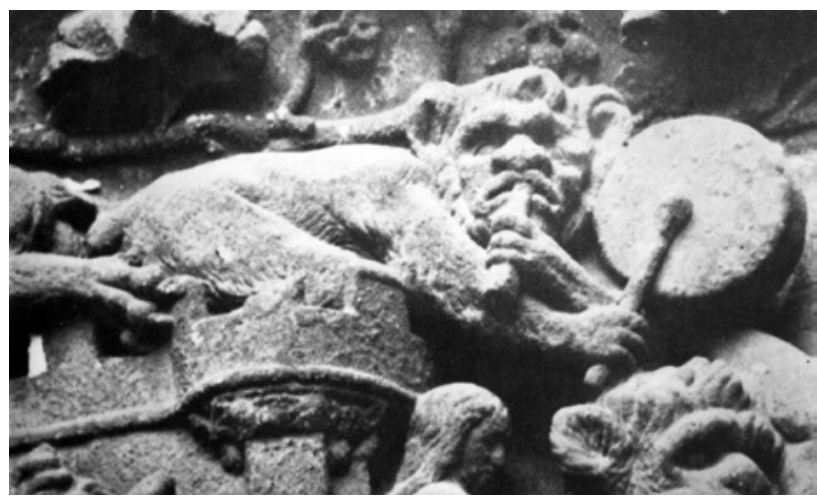

Fig. 4. St.-Denis abbey (Paris), tomb of Dagobert I, detail.

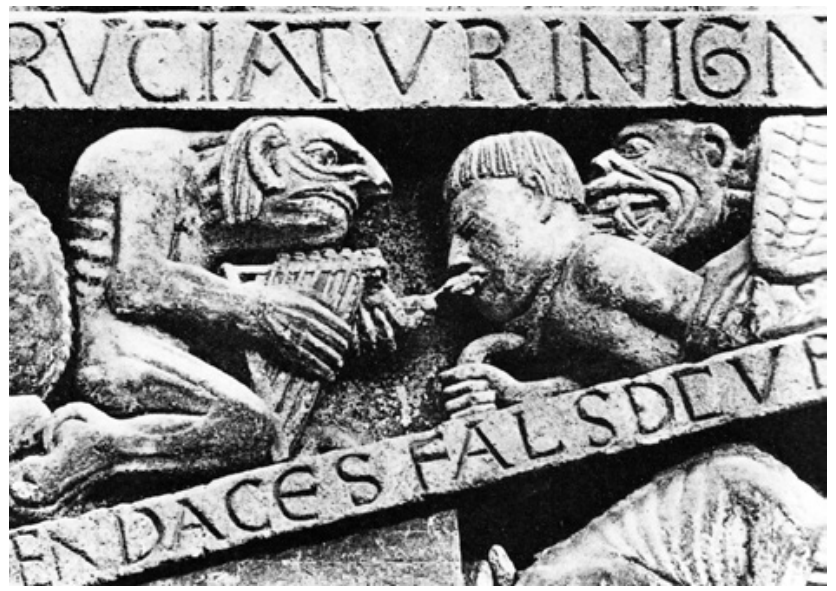

Fig. 5. Sainte-Foy abbey church at Conques (Aveyron), tympanum of the western portal.

${ }^{9}$ See for instance the tomb of Dagobert I in the St.-Denis Abbey Church in Paris.

${ }^{10} \mathrm{On}$ the harp in iconography, see Bernd Kalusche, Harfenbedeutungen. Ideale, ästhetische und reale Funktionen eines Musikinstruments in der abendländischen Kunst. Eine Bedeutungsgeschichte, Frankfurt am Main, Peter Lang, 1986. 
Very common in sculptures and miniatures are animals playing music. Very frequent is the ass on the harp (Fig. 6), partly inspired by Phaedrus' fable, but more precisely derived from a passage of Boethius, in which Philosophy addresses her listener, asking him whether he has understood her words or remains like the ass on the harp - with a metaphorical reference to ignorance. Bizarre and fanciful images of animals playing every kind of instrument populate the margins of gothic miniatures and possibly allude to the stupidity of entertainers, unlearned in music and only capable of displaying their poor skills and making themselves ridiculous. In a miniature from the Breviary of Renaud de Bar, for instance, a rabbit playing a bagpipe makes a naked man with a head on his ass dance: connotations related to the instrument reinforce this humorous allusion to the anal threat ${ }^{11}$, while the image casts a negative light on base musical entertainments performed by stupid creatures ${ }^{12}$ (Fig. 7).

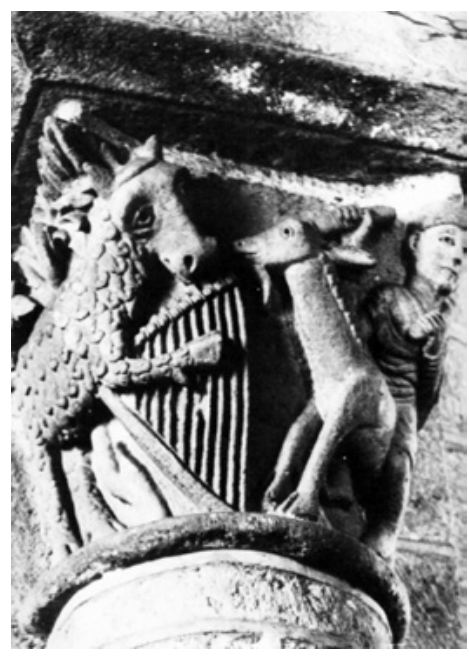

Fig. 6. Saint-Nectaire (Puy de Dôme), church capital

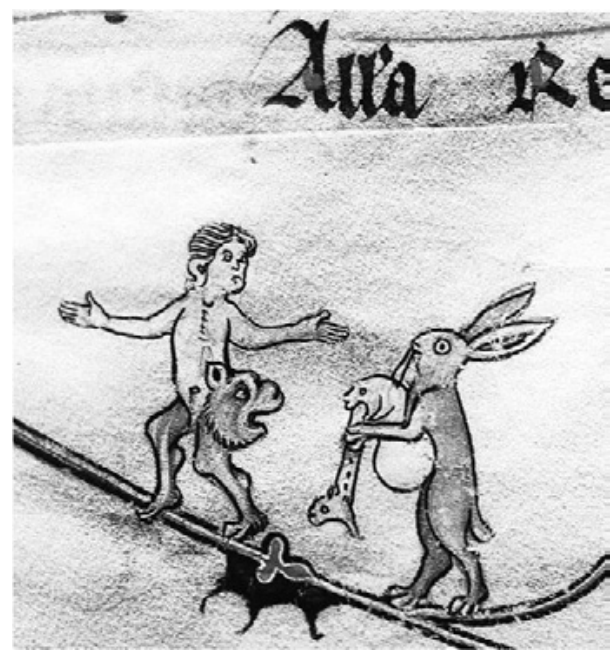

Fig. 7. (C) The British Library Board, Breviary of Marguerite de Bar, ms. Yate Thompson 8, f. 101.

\section{Holy and devilish music: signs of ambiguity in the margins}

As can be seen in many miniatures, the profane music of jesters is often depicted in opposition to King David's holy music. The dichotomy between good and bad music is very clear in the first Psalm illustration of the Salterio

${ }^{11}$ On the bagpipe, see Pierre Bec, La Cornemuse. Sens et histoire de ses désignations, Toulouse, Conservatoire occitan, 1996.

${ }^{12}$ Breviary of Marguerite de Bar, London, British Library, ms. Yate Thompson 8, f. 101, dating at the beginning of $14^{\text {th }}$ century. 
triplex, where a grinding devil-bear occupies the lower box of the miniature and is counterpoised to the figure of David ${ }^{13}$. The image represents a perfect example of the opposition between holy and hellish music, between the Beatus vir and the consilium impiorum mentioned in the text of the Psalm.

At any rate, as happened with the iconography of devils, which gradually became more and more comical, original marks of wickedness melted into the drôlerie of a mocking characterization, with the interpolation of signs typical of medieval imagery. And so, even heavenly creatures are exceptional objects of this parody, like a vielle-playing angel with a coarse staff replacing the usual bow or a hybrid angel playing bellows instead of a trumpet, introducing a touch of the grotesque into scenes from the Old and New Testament ${ }^{14}$. Such mingling of grotesque features is also evident in a miniature from the Belleville Breviary, illuminated around 1323-1326 by Jean Pucelle and his atelier. The initial illustrates the verses of Psalm 68, containing the sinner in the waters' plea to God representing worldly temptations ${ }^{15}$. The miniature shows St. Peter (instead of the more common David) crossing the sea in a boat under God's holy guidance. In the lower margin of the folium, the theme of hard trials to overcome is proposed again with a different iconographical development: in the middle a youth is receiving the benediction of a bishop, while on the left (the evil side) Delilah cuts Samson's hair - an action symbolizing weakness and vice - and on the right a personification of Strength stands on a lion ${ }^{16}$. Outside the frame, a hybrid angel plays a bellows instead of a trumpet ${ }^{17}$. Jean Wirth has ventured the conjecture that these kinds of depictions may contain ironic sexual hints specifically referring to the female aristocratic owners of manuscripts ${ }^{18}$, but with the exception of specific, single specimens this hypothesis does not seem sufficiently tenable.

${ }^{13}$ Salterio triplex. Cambridge, St. John College, ms. B. 18, f. 1. The manuscript comes from Reims, Saint-Rémi. On the miniature, see Chiara Frugoni, «La rappresentazione dei giullari nelle chiese fino al XII secolo», in Il contributo dei giullari alla drammaturgia italiana delle origini, ed. by F. Doglio, (Atti del II Convegno di Studio: Viterbo 17-19 giugno 1977), Roma, Bulzoni, 1978, pp. 113-134, p. 120 of reference. See also Dagmar Hoffmann-Axthelm, «Instrumentensymbolik und Aufführungspraxis. Zum Verhältnis von Symbolik und Realität in der mittelalterlichen Musikanschauung», in Basler Jahrbuch für historische Musikpraxis, 4 (1980), pp. 9-90, pp. 29-30 of reference, and Jean-Claude Schmitt, La raison des gestes: dans l'occident médiéval, Paris, Gallimard, 1990.

${ }^{14}$ Baltimore, Walters Art Museum, ms. W. 87, f. 52v.

${ }^{15}$ «Salvum me fac Deus quoniam intraverunt aquae usque ad animam meam»: Salmi, 68:2.

${ }^{16}$ For the interpretation of the sacred subject see François Avril, Manuscript Painting at the Court of France. The Fourteenth Century (1310-1380), New York, George Braziller, 1978, p. 62 of reference, who unfortunately dismisses the grotesque figures in the margins as lighter and joyful elements in the serious, didactic scheme.

${ }^{17}$ Breviario Belleville. Paris, Bibliothèque Nationale, ms. Lat. 10483 (and 10484), f. 37.

${ }^{18}$ Jean Wirth, Les marges à drôleries des manuscrits gotiques (1250-1350), Genève, Librairie Droz, 2008, pp. 247-252. 
Sometimes comic scenes could be conceived as a sort of charivari performed on the page through its marginal illustrations. But the parody of musical instruments may be also linked, in my opinion, to the theme of the upside down world and the staging of a carnivalesque disorder. In the specific case of the Belleville Breviary, what could be the meaning of the little monster, a sort of degenerated angel making a ridiculous gesture? Since he is depicted on the right side of the folium, alongside the allegory of Strength, a negative symbolic meaning seems to be excluded, but, on the other hand, considering it just as a simple decorative fancy would be a limited interpretation. More probably, the drôlerie is a reworking of the musical parody often represented in other contexts, here unusually applied to an angel, who becomes a sort of ridiculous half-demoniac creature, not by chance placed outside the frame.

\section{A satirical mingling of human and beastly features}

The parody of musical instruments has an evident comic purpose. But to what extent has it been conceived as a satire of a specific category of entertainers? The use of improper instruments could allude to the ignorance of jesters, who exhibit their practical musical skills without really knowing music. This would explain the recurrence of the playing ape, an animal often used in parodical contexts, and the frequent mingling of human and beastly features, with animals dressed as jesters and entertainers resembling animals - a topic to be found in miniatures and reliefs through at least the $15^{\text {th }}$ century (Fig. 8). In a marginal miniature from the Hours of Maastricht, an ape ride a wild boar playing a ladle as a trumpet (Fig. 9).

In a miniature from a $14^{\text {th }}$ century manuscript of the Lancelot $d u L a c$ a harp-playing ape with a jester's cap is accompanying a battle of sex, that is, fighting between a man and a woman ${ }^{19}$. The employment of this despised animal, the ape, seems to introduce a more composite mingling of meanings in a miniature from a Psalter that belonged to Geoffroy d'Apremont, in which a harpist monkey goes so far as to mimic David, the holy exemplary musician (Fig. 10).

${ }^{19}$ Lancelot du Lac, Manchester, John Rylands Library, ms. fr. 1, f. 82. 


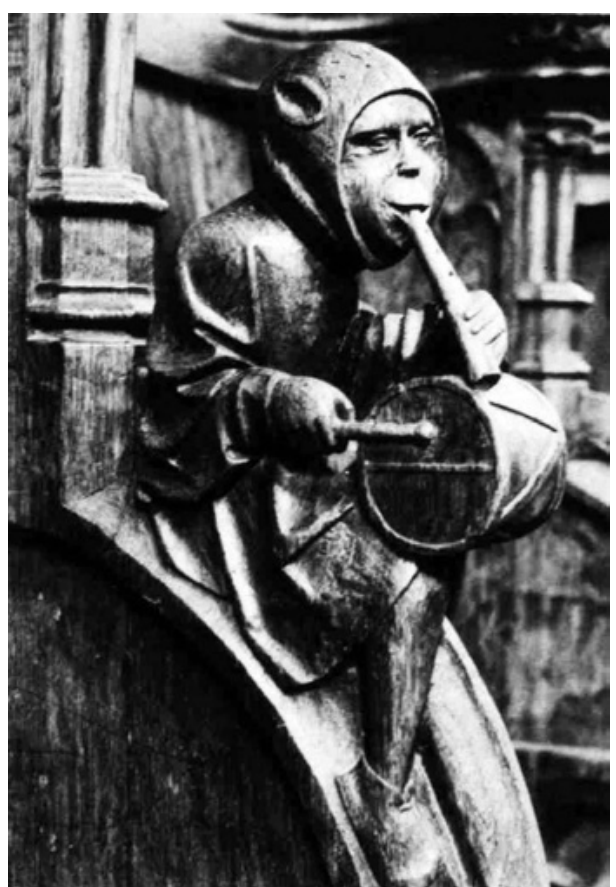

Fig. 8. Sainte Katerina Churchat Hoogstraeten (Antwerp), choir stall.

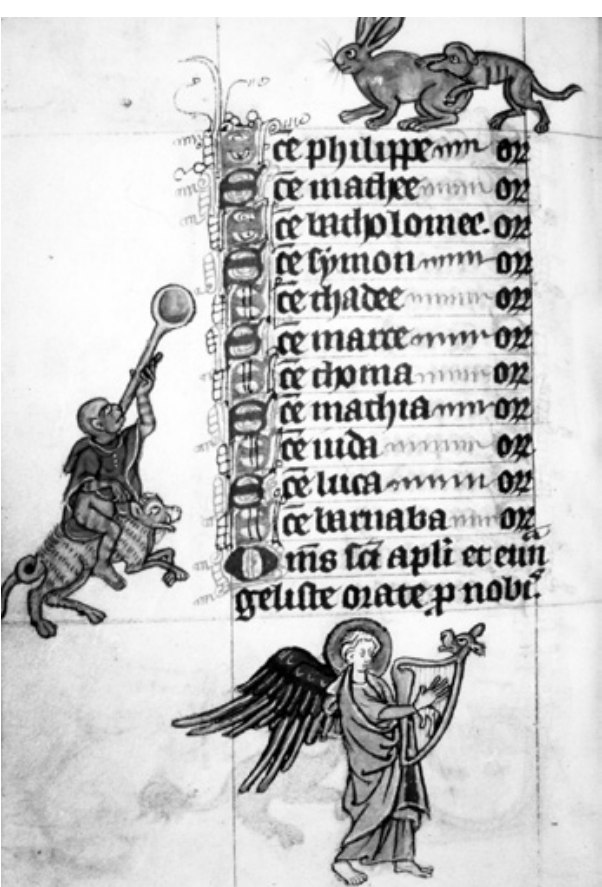

Fig. 9. (c) The British Library Board, Hours of Maastricht, ms. Stowe 17, f. 173v.

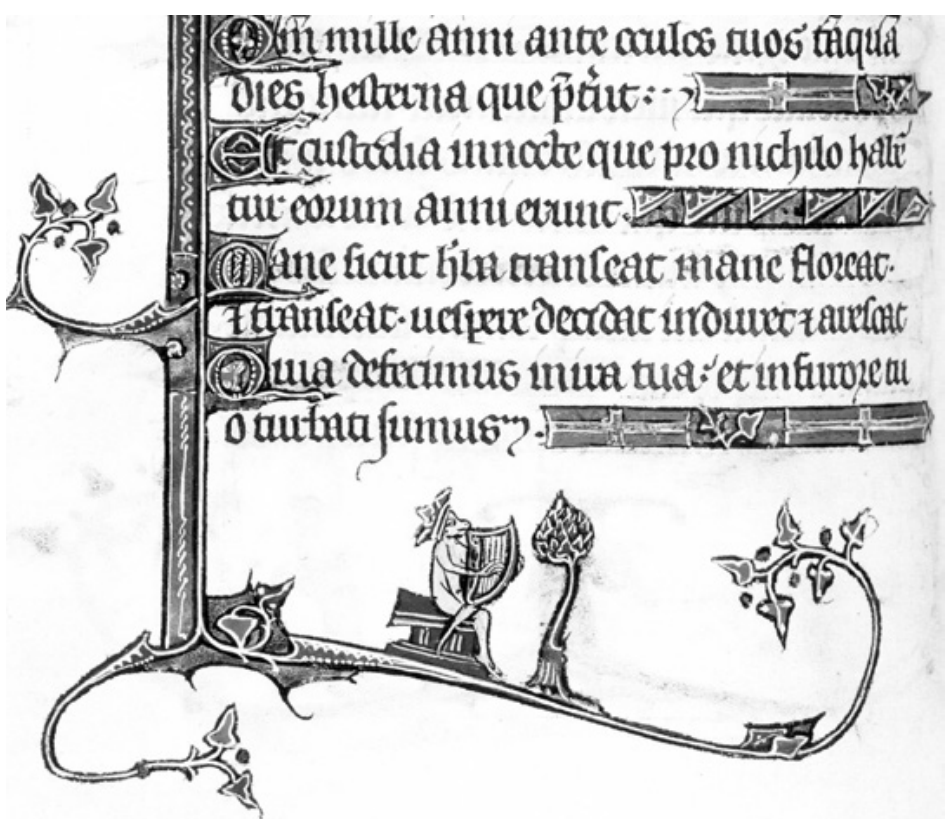

Fig. 10. Oxford, Bodleian Library, ms. Douce 118, f. 101v. 
It wears a sort of red mantle with a cap that evokes the typical costume of jesters. Its incongruous attire makes it appear even more obscene and ridiculous, because it is unseemly, like the unjustified nudity of human beings. These negative allusions combine with a possible metaphorical connotation, since the ape, an impure and stupid animal imitating the actions of a musician, is riding a wild boar, which, according to the Bible, ravages the vineyards (Psalm 79, 14), destroying the fruits of God: Exterminavit eam aper de silva et singularis ferus depastus est eam (The boar out of the wood hath laid it waste: and a singular wild beast hath devoured it). The negative sense of this player-ape is emphasised by its juxtaposition with a harp-playing angel depicted in the lower margin. Sacred music, celebrating the praise of God, is opposed to ridiculous profane music, ravaging the spiritual harvest by corrupting human souls, inciting them to sin.

A musical parody can sometimes assume satirical connotations addressed to a specific class or category of medieval society. In a miniature from the Hours of Maastricht, a cleric plays bellows with a distaff to provide rhythm for a dancing woman, who in fact resembles a disguised cleric more than a jongleresse (Fig. 11). Depictions of clerics, monks or nuns playing music are occasionally present in Gothic manuscripts, but the employment of impossible instruments - which are in fact objects typical of everyday female occupations - casts a mocking light on the scene. A sharp satiric purpose seems entailed in a miniature from a manuscript of Ramón de Penyafort's Summa de poenitentia, dating to the beginning of $14^{\text {th }}$ century, where we can see St. Francis of Assisi preaching to the $\operatorname{birds}^{20}$ (Fig. 12).

The anecdote relating his imitation of a jester's way of playing a vielle is well known, and so it becomes a provocative subversion of the values implied in the incitement he gives his brothers to sing the praise of God tamquam ioculatores Domini ${ }^{21}$. Besides the saint, another Franciscan (unmistakably recognizable by his pointed cap) is listening to the sermon, while an ape playing a vielle sits on the ground behind him. The animal imitates the attitude of the friar, especially in the posture of its legs, and seems to mimic the gestures of the musician, offering to the observer a sort of negative alter ego of that figure. In doing so, it also hints at the despicable image of the

\footnotetext{
${ }^{20}$ That the monkey musician suggests a disquieting note has been affirmed by Roberto Rusconi, "'Trasse la storia per farne una tavola': immagini di predicatori degli ordini mendicanti nei secoli XIII e XIV», in La predicazione dei frati dalla metà del '200 alla fine del '300 (Atti del XXII Convegno Internazionale, Assisi, 13-15 ottobre 1994), Spoleto, Centro Italiano di Studi sull'Alto Medioevo, 1995, pp. 405-450, p. 449 of reference.

${ }^{21}$ Scripta Leonis, XLIII, p. 166 (cit. in Chiara Frugoni, Francesco e l'invenzione delle stimmate. Una storia per parole e immagini fino a Bonaventura e Giotto, Torino, Einaudi, 1993, p. 394, n. 82).
} 
jester - not an example of voluntary humiliation such as St. Francis, but a debased model giving a satirical hue to the scene.

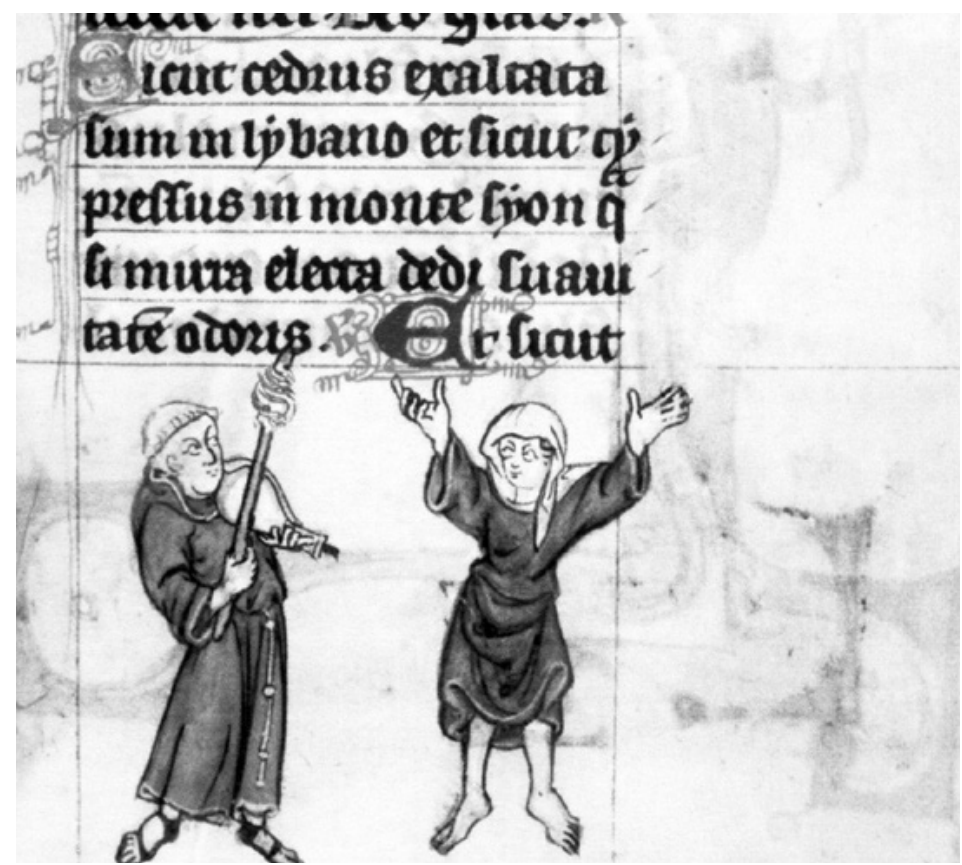

Fig. 11. (C) The British Library Board, Hours of Maastricht, ms. Stowe 17, f. 38.

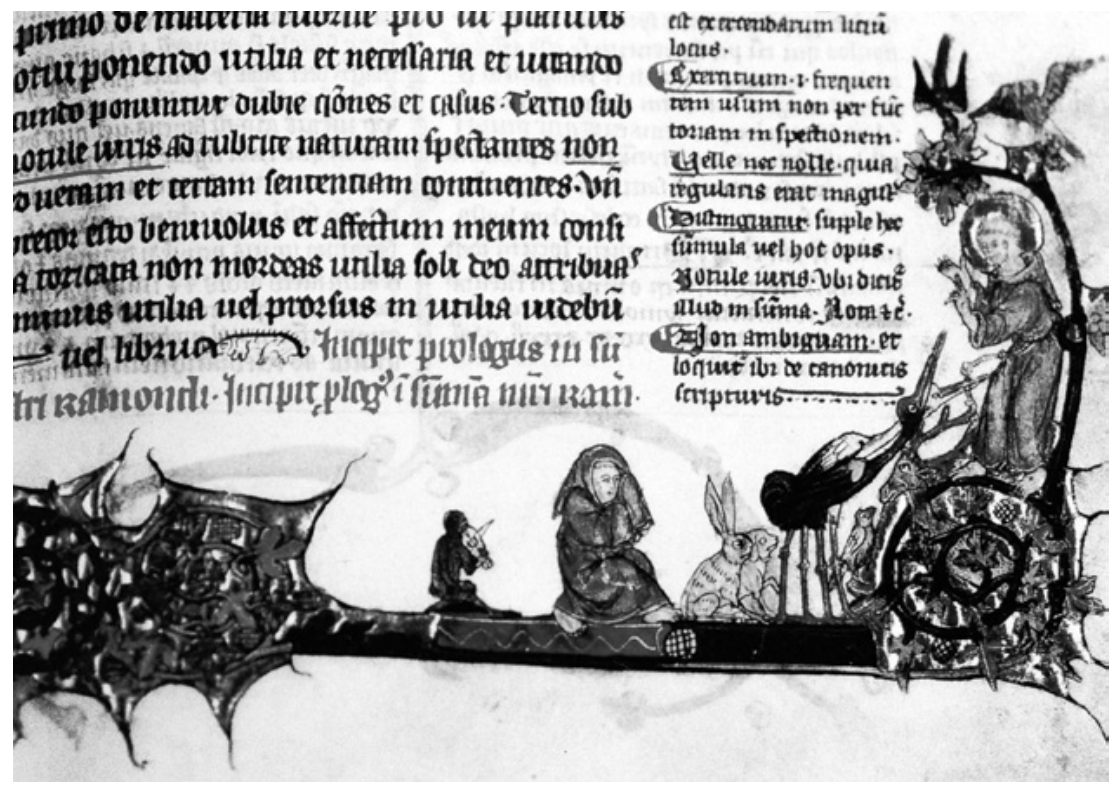

Fig. 12. Liège, Bibliothèque Alpha, ms. 137C, f. 17. 


\section{The ass's jawbone as a musical instrument}

Within the context of musical parody, a much more puzzling instrument is sometimes depicted in marginal miniatures: an ass's jawbone, employed by the artists to replace the vielle or the guitern. In a Franco-Flemish manuscript of the romance Voeux du Paon by Jacques de Longuyon, dating to the middle of $14^{\text {th }}$ century, we can see an example in which the jawbone is played with tongs by a mermaid ${ }^{22}$. The negative connotations of mermaids during the Middles Ages are well known: representing sensual allurements and female seduction, they play a music leading men astray from virtue and making them fall headlong into sin. Considered from this particular point of view, the presence of an improper musical instrument is likely to be something more than a mere allusion to a lack of musical knowledge and an ignorance of the laws of harmony. It seems rather to be a reference to the dangerous power of music as an irrational force, employed as a means of seduction and the murder of souls. The substitution of the vielle by an ass's jawbone clearly confirms this shift from simple parody to moral judgement.

The object has in fact very bad connotations, since in many depictions of medieval western art an animal's jawbone is the weapon used by Cain to kill his brother in the fields. Why have the artists chosen this detail? Art historians dwelling on this point have come to various conclusions, beginning from Shapiro's philological hypothesis ${ }^{23}$ rejected in 1961 by Henderson, who tries to demonstrate that the object derives from Samson's iconography and in particular from a misunderstanding by the illustrator of an English Psalter ${ }^{24}$. An article by Barb published eleven years later contributed to the subject by recurring to certain pieces of evidence ${ }^{25}$. First of all, the term used in the Bible refers to a bloody slaughtering, likely using a cutting instrument such as the sickle. Moreover, in ancient eastern depictions of harvesting scenes the sickle is often represented as a jawbone, with visible teeth, and Barb has demonstrated the existence of intermediate specimens, with flints inserted into an animal's jawbone in order to turn it into a weapon. Besides the mingling of eastern and western culture, we can notice a perfect coincidence with the two main contexts to which the parody of musical instruments can be

\footnotetext{
${ }^{22}$ Jacques de Longuyon, Voeux du Paon, New York, Pierpont Morgan Library, ms. Glazier 24, f. 16.

${ }^{23}$ Meyer Schapiro, «Cain's Jaw-Bone that did the first Murder», in Art Bulletin, 3:24 (1942), pp. 205-212.

${ }^{24}$ George Henderson, «Cain's Jaw-Bone», in Journal of the Warburg Institute and Courtauld Institutes, 1/2:24 (1961), pp. 108-114. The manuscript is the Cotton Claudius B.IV (London, British Library).

${ }^{25}$ A.A. Barb, «Cain's Murder-Weapon and Samson's Jawbone of an Ass», in Journal of the Warburg Institute, 35 (1972), pp. 386-389.
} 
referred: the agricultural and the culinary worlds. The ass's jawbone depicted in Franco-Flemish Gothic miniatures is, once again, a harvest tool improperly used. But to the eyes of a learned medieval observer it could also evoke the weapon of the first crime, with an allusion to a very negative moral action. Moreover, in the case of this specific miniature, the reprobation is reinforced by the choice of a sinful, long haired and nude-breasted mermaid instead of a simple musician.

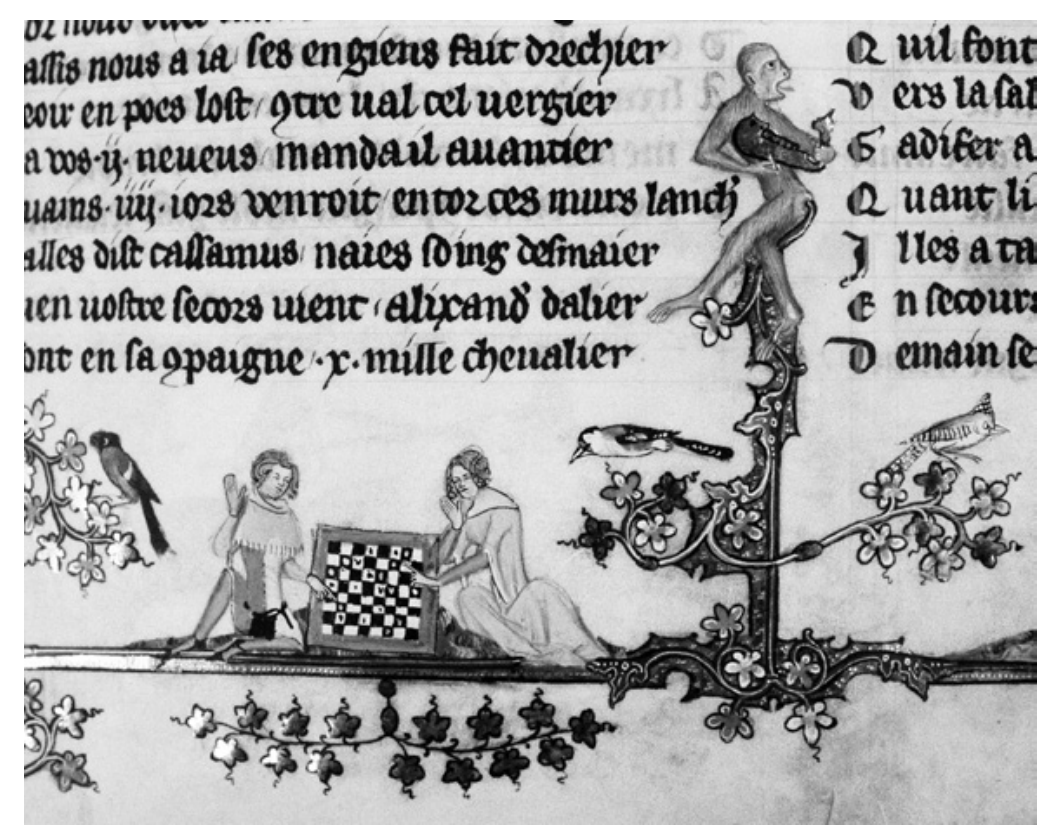

Fig. 13. Roman d'Alexandre, Oxford, Bodleian Library, ms. Bodley 264, f. 112.

In some miniatures, the ass's jawbone employed as a musical instrument gives to the scene a grotesque connotation, such as in one from the Hours of Jeanne d'Évreux, where a goat is playing a jawbone with a rake ${ }^{26}$. Let's take into consideration another puzzling marginal miniature. In a folium from the Roman d'Alexandre, a humanized ape, precariously perched on a decorative shoot, plays an ass's jawbone and opens its mouth wide to sing, displaying a long and pointed tongue resembling that of a snake (Fig. 13). This latter animal is also evoked by the unnatural turning of the monkey's body, a distortion which clearly hints at a monstrous turpitude and the idea of self- transformation for spectacular purposes. The ape can play only cacophonic music, and it is not by chance that this soul's murdering music accompanies the

${ }^{26}$ Hours of Jeanne d'Évreux, New York, The Metropolitan Museum of Art, The Cloisters, ms. Acc. 54.1.2, f. 22 . 
sinful pastime of a courtly couple in the lower margin, the chess game (often depicted in miniatures as a means of economic ruin and moral perdition). In spite of the courtly context, the moral judgement is sharp and the depiction of a despised animal like the ape casts a sinister light on worldly entertainments.

\section{Aping the musician: a parody of entertainers}

During the Middle Ages, apes are frequently depicted in the marginal miniatures as trained animals accompanying the jesters. In medieval iconography the ape is also often employed in the place of entertainers, extending a similarity full of negative consequences: just as this animal imitates everything without understanding the meaning of anything, jesters and popular players do not know the laws of music and make themselves ridiculous. Referring to the difference between musician and chorister, Guido d'Arezzo had stated around the year 1000: the former knows the art of music, while the latter only has the practice, and qui facit quod non sapit diffinitur bestia ${ }^{27}$ (the man who does not know what he does can be called a beast) - a concept that had been already expressed by St. Augustine ${ }^{28}$.

As I am trying to demonstrate, in many cases the parody of musical instruments could be interpreted as a satire of the entertainers, often depicted in the droleries of marginal miniatures. In the Hours of Jeanne d'Évreux, illuminated by Jean Pucelle before 1328, a jawbone is played by a hybrid king training a dog to dance ${ }^{29}$. This sort of disharmonic and monstrous anti-music is depicted in the lower margin of the folium, while in the initial the Nativity is represented. Is the marginal monarch a parodistic overturning of the just born true king, Jesus Christ? Michael Camille has observed that many medieval miniatures can be interpreted as intentional misunderstandings of a text and contrapositions between high and low, centre and margins ${ }^{30}$. Not all the examples he proposes are completely convincing, but the theory seems reasonably applicable to many of them. In the Hours of Jeanne d'Évreux miniature, the mirroring between the centre and the margin seems to be a matter of

${ }^{27}$ Guido d'Arezzo: «Musicorum et cantorum magna est distantia: / Isti dicunt, illi sciunt, quae componit musica. / Nam qui facit, quod non sapit, diffinitur bestia» (vv. 1-3).

${ }^{28}$ Agostino, De ordine, II, 19: «Deinde quis bonus cantator, etiamsi musicae sit imperitus, non ipso sensu naturali et rhythmum et melos perceptum memoria custodiat in canendo, quo quid fieri numerosius potest? Hoc nescit indoctus, sed tamen facit operante natura. Quando autem melior et pecoribus praeponendus? quando novit, quod faciat. Nihil aliud me pecori praeponit, nisi quod rationale animal sum» (CC. SL 29).

${ }^{29}$ Hours of Jeanne d'Évreux, op. cit., f. 54.

${ }^{30}$ Michael Camille, Image on the Edge. The Margins of Medieval Art, London, Reaktion Books, 1992. 
fact and can be read as an opposition, hinting at an underworld of monstrous infernal creatures, parodying sacred scenes. In fact, as is known, the initials followed an iconographical programme established by the authorities, while the marginal miniatures were left to the inspiration of the artists' fancy. A different interpretation of the Hours of Jeanne d'Évreux miniature has been proposed by Martine Cluzot, who associates the king with the manuscript's owner, Jeanne d'Évreux, accused of adultery, and tries to explain the hybrid players as a sort of charivari, hinting at the immorality of the court ${ }^{31}$. But if the folkloric context of charivari could be seen as a juxtaposition to the religious theme in the initial, the latter seems scarcely relatable to the book's owner, Jeanne, and the marginal wicked king seems rather to represent an overturning of the true newly born monarch, Jesus Christ.

On another folium of the same manuscript, a dog is playing a bone as a pipe while a man disguised as a goat makes music with a jawbone and a rake: the lower part of his body is clearly a costume, from which a human arm emerges. Emphasizing this disguise, Jean Pucelle would probably suggest an allusion to jesters, who are sometimes associated with the most disgusting and lascivious animals. Around the middle of the $13^{\text {th }}$ century, the Dominican Guglielmus Peraldus considered the goat and the ape as foetida animals, which he associated with the buffoon, because all of them are instruments used by the devil to make people laugh: Notandum ergo quod scurra est velut capra, vel simia, cum quibus ludit diabolus, \& homines excitat ad risum. Capra animal foetidum est. Simia animal deforme. Sic tales valde foetidi sunt \& valde deformes ${ }^{32}$ (It must be noted that scurra is like the goat, or the ape, with which the devil play exciting men to laughter. The goat is a disgusting animal. The ape is a deformed animal. So both are strongly disgusting and deformed.) By altering their natural appearance, jesters lose any human resemblance to God, making themselves similar to beasts. Guglielmus also defined laughter as a sort of ebullition at the fire of concupiscence, through which the buffoon inflates the wind of vanity. In the next century, the same assimilation of jesters to apes and goats can be found in Domenico Cavalca's Pungilingua, which refers to their speeches as dishonest and $\operatorname{sinful}^{33}$. It is worth remembering that hypothetical reconstructions of the jesters' repertory mostly draw from strongly prejudicial sources of information: condemna-

${ }^{31}$ Martine Cluzot, «La musique des marges. L'iconographie des animaux et des êtres hybrides musiciens dans les manuscrits enluminés du XII ${ }^{\mathrm{e}}$ au XIV ${ }^{\mathrm{e}}$ siècle», in Cahiers de civilisation médiévale, 168:42 (1999), pp. 323-342, p. 328 of reference.

${ }^{32}$ Guglielmo Peraldo, Summa virtutum, ac vitiorum, Lugduni, Gulielmum Rovillium, 1585, p. 589 [but 590].

${ }^{33}$ Domenico Cavalca, Pungilingua (1476-1477), Firenze, Nicolò di Lorenzo, XXVII. 
tions by Christian writers, who often mention the jesters and their spectacles as examples of moral perversion. Because the entertainers incite to worldly pleasures and sensual joys, they are considered accomplices of evil forces and defined as ministri Satanae and apostoli daemonum ${ }^{34}$. Described as degenerate and corrupt creatures without any hope of salvation, the entertainers are also compared to the most despised animals. Exciting men to pleasure, they divert them from more important occupations and meditations, that is, from thoughts of punishments and rewards beyond this world.

\section{Bizarre bagpipes and a coturnatus performer}

As I have observed, the parody of musical instruments reaches its climax in the $14^{\text {th }}$ century, but some specimens can be occasionally found also in older manuscripts. In the Hours of Maastricht we can see a bizarre miniature showing a hybrid with paws playing a cock with tongs, accompanied by a harp-playing hare (Fig. 14). The cock is employed as a wind instrument, with a bizarre imagery which - as far as I know - would not be re-proposed in the next century. Browsing additional ancient manuscripts, I found a possible source of inspiration for this odd iconography in a miniature in a $12^{\text {th }}$ century codex of the Commentarium on the Apocalypse, from Silos (Fig. 15).
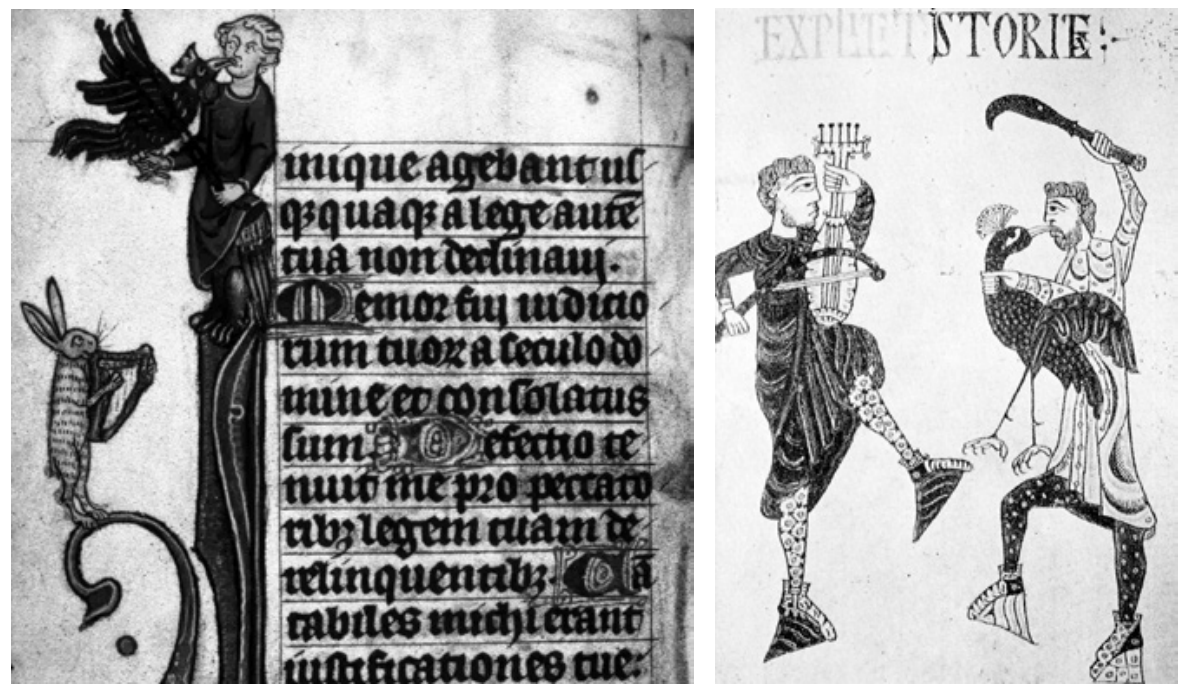

Fig. 14 (Left). (C) The British Library Board, Hours of Maastricht, ms. Stowe 17, f. 92v.

Fig. 15 (Right). (C) The British Library Board, Commentarius in Apocalypsin, ms. Add. 11695, f. 86.

${ }^{34}$ Respectively, Onorius de Autun, Elucidarium sive dialogus de summa totius christianae theologiae, II (PL 172, 1148) and Petrus Abelardus, Theologia Christiana, II, 129 (CC.CM 12). 
Surviving in at least 26 illuminated copies, the text was written by Beatus of Liebana in the $8^{\text {th }}$ century. The manuscript to which I refer is in the British Library and was copied at the end of the $11^{\text {th }}$ century; One of the illustrations depicts two fanciful jugglers - debased heirs of the ancient actor - dressed in oriental costumes and wearing very high shoes, most probably a misunderstood re-elaboration of the mythic coturni of the ancient tragic actor. In fact, they had been reinterpreted as high shoes by learned medieval commentators, probably because of the adjectives metaphorically used to describe them as a "grande et altum calceamentum". But another striking element in the miniature is the impossible bagpipe represented by the peacock, whose beak is held in the mouth of the other juggler, who raises a scimitar and holds the poor beast by the neck. Which is the sense of this odd use of a peacock as a wind instrument? Does the image contain an obscene allusion? We can observe that bagpipes were often used in later western iconography, as a possible reference to genitals and sexual practices. Moreover, it is not infrequent to find bizarre players of impossible wind instruments blowing into the tail of an animal, such as in a marginal miniature in the Hours of Jeanne d'Évreux ${ }^{35}$.

\section{Making music with animals: the improper use of the body}

At any rate, in my opinion this particular iconography cannot be simply explained as a sexual allusion. The gesture of blowing or biting a dog's tail occasionally appears in another context, surprisingly a religious one: the illustration of Psalm 52 (53). From the $13^{\text {th }}$ century on, the initial of the Psalm verses, "Dixit insipiens in corde suo: Non est Deus" often displays an image of a fool denying the existence of God $^{36}$. Beginning from the XII ${ }^{\text {th }}$ century, artists began to illustrate the Psalm with the figure of a standing, half-naked man carrying a club, disputing with a king and often stared down at from a cloud by God. Later on, the insipiens acquired the typical aspect of a court

\footnotetext{
${ }^{35}$ Hours of Jeanne d'Évreux, New York, The Metropolitan Museum of Art, The Cloisters, ms. Acc. 54.1 .2$, f. $34 \mathrm{v}$.

${ }^{36}$ On this subject, see Douglas J. Gifford, «Iconographical Notes towards a Definition of the Medieval Fool», in Journal of the Warburg Institute, 37 (1974), pp. 336-342; Dagmar Langenfeld, Irene Götz, «Nos stulti nudi sumus - Wir Narren sind nackt», in Narren, Schellen und Marotten. Elf Beiträge zur Narrenidee, ed. W. Mezger, Remscheid, Ute Kierdorf, 1984, pp. 37-96; M. Assirelli, «L'immagine dello 'stolto' nel Salmo 52», in Il codice miniato. Rapporti tra codice, testo e figurazione, (Atti del III Congresso di Storia della Miniatura, Cortona, 20-23 ottobre 1988), ed. by M. Ceccanti, M. C. Castelli, Firenze, Olschki, 1992, pp. 19-34; Sandra Pietrini, «Medieval Fools in Biblical Iconography», in Medieval English Theatre, 24 (2002), pp. 79-103; and «Stolti, buffoni e chierici nell'iconografia medievale», in Quaderni Medievali, 56 (2003), pp. 14-56; Tito Saffioti, «L'insipiens del Salmo 52: da folle medievale a buffone di corte», in La scena assente? Realtà e leggenda sul teatro nel Medioevo, (Atti del Convegno di Studi, Siena, Certosa di Pontignano, 13-16 giugno 2004), Alessandria, Edizioni dell’Orso, 2006, pp. 417-448.
} 
fool, through an evolution that presents puzzling intermediate stages in some Flemish Psalters of the late $13^{\text {th }}$ century. In some miniatures illustrating the Psalm, the fool bites the tail of a dog, with a gesture which could given rise to a debate on its interpretation ${ }^{37}$ (Fig. 16).

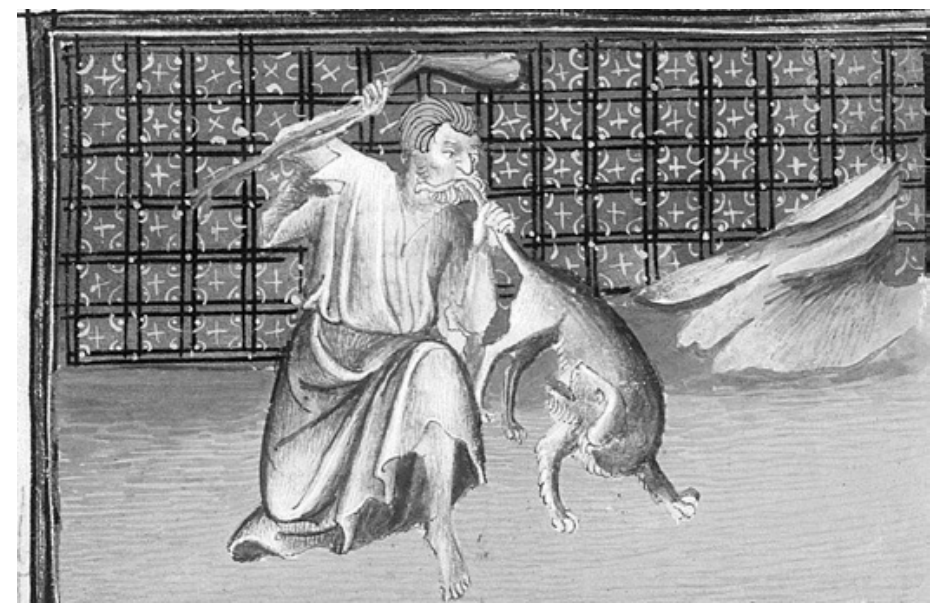

Fig. 16. (C) The British Library Board, ms. Royal 19 D VI, f. 267v.

Discussing this puzzling variant, Angelika Gross has proposed several hypotheses: it might be due to a confusion of the word panis with canis, a satire on the cynics, or simply an allusion to the stupidity of the insipiens, incapable of distinguishing between a game and a dangerous action ${ }^{38}$. In my opinion, this inexplicable iconography has a different meaning, related to the parody of musical instruments. I will try to explain this possible connection between these two subjects by recurring to some examples. In the wooden sculpture of a choir stall in St. Botolph, Boston (Lincolnshire), dating around 1390, two mirrored buffoons have their lips on the tail of a cat, playing it like a bagpipe (Fig. 17). It is not surprising to find such subjects on the misericords of late medieval churches, which were invisible to the congregation during the Mass and were thus left to the free imagination of artists. A parodical scene of the

\footnotetext{
${ }^{37}$ See for instance two manuscripts of the Bible Historiale - one dated 1372 (Den Haag, Museum Meermanno Westreenianum, ms. 10 B 23, f. 293) and the other 1418-1420 (Fig. 16). The gesture can be seen also in some $14^{\text {th }}$ century manuscripts (for example Paris, Bibliothèque Nationale, ms. fr. 3 , f. $277 \mathrm{v}$ and Paris, Bibliothèque de l'Arsenal, ms. 5057, f. 276v).

${ }^{38}$ Angelika Gross, Das Bild des Narren: Von Psalm 52 zu Sebastian Brant, in Bild und Abbild vom Menschen im Mittelalter, (Akten der Akademie Friesach 'Stadt und Kultur im Mittelalter': Friesach (Kärnten), 9-13 September 1998), ed. by E. Vavra, Klagenfurt, Wieser Verlag, pp. 273-292. See also Angelika Gross, «Tristan, Robert le Diable und die Ikonographie des Insipiens: der Hund als Neues Motiv in einem Alten Kontext», in Schelme und Narren in den Literaturen des Mittelalters, Eulenspiegelstadt Mölln, 24.-27. September 1992, Greifswald, Reineke Verlag, 1994, pp. 55-71.
} 
same genre appears in a choir stall in Norwich Cathedral (Fig. 18): an ape wearing a jester's costume 'plays' an animal like a bagpipe, while another ape and a laughing dog with a psaltery observe the strange performance.

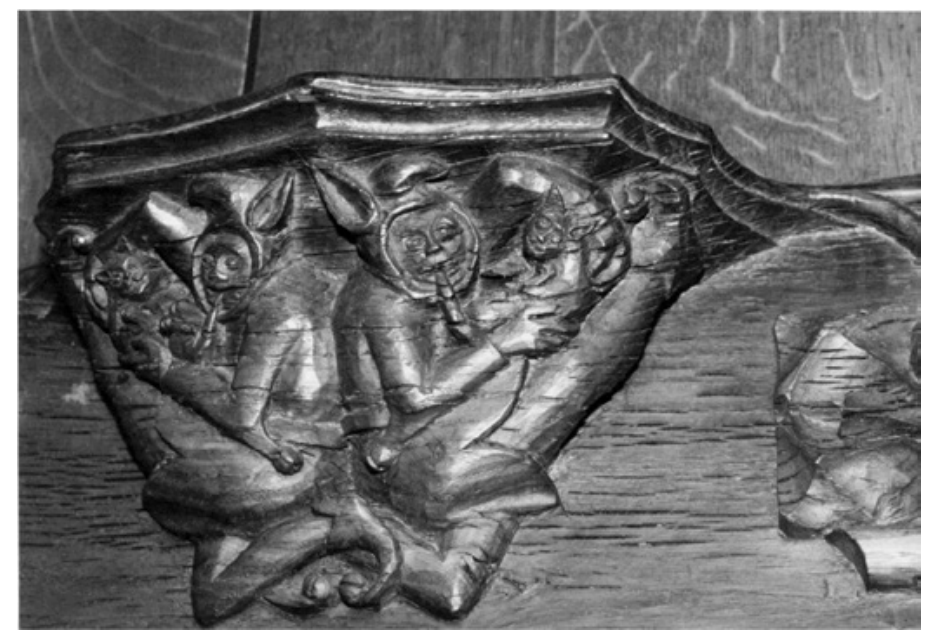

Fig. 17. St. Botolph, Boston (Lincolnshire), choir stall, wooden sculpture.

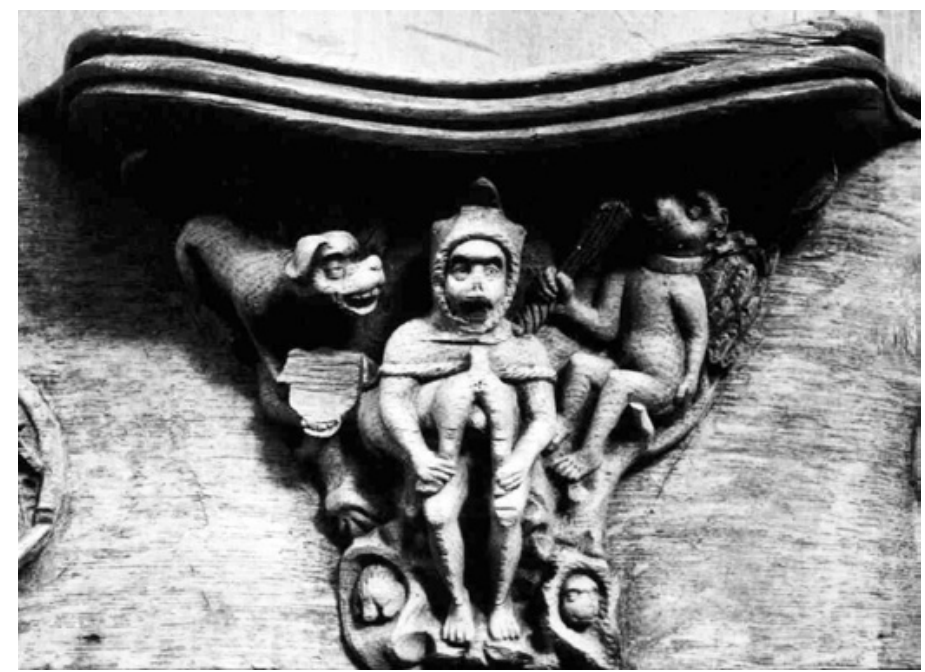

Fig. 18. Norwich Cathedral, choir stall.

Behind the humorous vein, a metaphorical meaning may creep into the beholder's mind: the ape making music with an animal represents the jesters who abase themselves in contemptible performances as devil's instruments to make people laugh. In fact, the $13^{\text {th }}$ century preacher Bertold from 
Ratisbon defined the jesters in a figurative metaphor as tiuvels blâsbelge («devil's bagpipes») $)^{39}$.

Animals played as musical instruments cast a sinister light on the comedy of the scene, representing an inversion of the natural order of things and the triumph of senseless brutality. The playing beast is, moreover, tied down by the other ape, as though to symbolize the enslavement to sin of all these wicked creatures, simultaneously accomplices and victims of the devil. But the most striking feature is that of reducing the animal to a musical instrument, just as in the miniatures illustrating the foolishness of the insipiens. The sculptures mentioned cast a new, sinister light on the cited miniature from the Hours of Jeanne d'Évreux and the illustrations of Psalm 52: biting a dog's tail is not just a childish game, due to the silliness of the insipiens, but possibly an allusion to playing a musical instrument, with an action that implies a parody, because it reifies the animal and abases the human being to the status of a bestial, stupid creature. As these examples should demonstrate, the parody of musical instruments is not a mere variant of the medieval comic attitude to reinterpret the real world, but can have strong negative implications linked to the condemnations of worldly entertainments and to the ignorance on the laws of music, since it is enacted resorting to the more striking signs of an infernal comic bestiality.

Recibido: 08/05/2017

Aceptado: 12/07/2017

\footnotetext{
${ }^{39}$ Hammerstein, op. cit., p. 51. On the condamnations of medieval entertainers see Sandra Pietrini, $I$ giullari nell'immaginario medievale, Roma, Bulzoni, 2011.
} 


\title{
$\cos$
}

\section{The Parody of Musical Instruments in Medieval Iconography}

\begin{abstract}
The vast field of musical iconography during the Middle Ages must necessarily deal with the rich and surprising imagery of western manuscripts, showing a fanciful proliferation of playing creatures and bizarre deformations, sometimes inspired by exotic suggestions. In marginal miniatures of $14^{\text {th }}$ century we can discover an interesting and puzzling topic: the parody of entertainers, with hybrid men playing a vielle with tongs, mermaids or apes playing jawbones and so on. The spreading of this topic in medieval iconography is linked to a satirical purpose aimed at professional entertainers, harshly condemned by Christian writers. Strange instruments made out of everyday objects like grills and distaffs, or 'exotic' animals like peacocks, mingle in the grotesque underworld of marginal miniatures, in which the noble art of music is often replaced by the cacophonous noises suggested by the devil.
\end{abstract}

Keywords: Middle Ages. Musical Iconography. Jesters. Parody. Marginalia.

LA PARODIA DE LOS INSTRUMENTOS MUSICALES EN LA ICONOGRAFÍA MEDIEVAL

RESUMEN: El vasto campo de la iconografía musical durante la Edad Media debe ocuparse necesariamente de las ricas y sorprendentes imágenes que se encuentran en algunos manuscritos occidentales y que muestran una proliferación de criaturas que tocan y se contorsionan a menudo inspiradas por exóticas reminiscencias. En los marginalia del siglo XIV puede descubrirse un tema interesante y desconcertante a la vez, la parodia de los entretenedores: hombres híbridos que tocan la viola con pinzas, sirenas o monos tocando con mandíbulas y así sucesivamente. La difusión que tuvo este tema en la iconografía medieval se ha relacionado con una finalidad satírica dirigida a los entretenedores profesionales, condenados muchas veces por los escritores. Instrumentos extraños hechos con objetos cotidianos como parrillas y ruecas, o animales exóticos como los pavos reales se mezclan en el grotesco submundo de los marginalia, en las que el noble arte de la música es a menudo reemplazado por los ruidos cacofónicos que sugiere el diablo.

Palabras Claves: Edad Media. Iconografía musical. Juglares. Parodia. Marginalia. 